\title{
Career Success Factors of Women in the Public Sector: An Empirical Analysis of the Korean Central Government
}

\author{
Yujin Choi ${ }^{1}$ \\ ${ }^{1}$ Department of Public Administration, Ewha Womans University, Seoul, South Korea \\ Correspondence: Yujin Choi, Department of Public Administration, Ewha Womans University, Seoul, South \\ Korea. E-mail: yujinchoi@ewha.ac.kr
}

Received: December 31, 2014 Accepted: February 3, 2015 Online Published: April 2, 2015

doi:10.5539/ass.v11n9p300

URL: http://dx.doi.org/10.5539/ass.v11n9p300

\begin{abstract}
The present study examines why some women are more successful in their careers than others. Although considerable research has been conducted on determining factors in women's career success in the private sector, those factors in the public sector remain under-researched. Two main goals of this study are (1) to investigate the factors affecting the career success of women in the public sector and (2) to assess the relative importance of personal factors and situational factors for women's career success. This study empirically tests a comprehensive model of career success that includes both objective and subjective elements using a survey of female public officials in the Korean central government. The results reveal that personal factors are associated more with women's objective career success than situational factors, and situational factors are related more to the subjective career success than personal factors.
\end{abstract}

Keywords: career success, gender, female public managers, South Korea

\section{Introduction}

As women's participation in the public sector has increased dramatically over recent decades, issues relating to women's careers have become more important. It is evident that many obstacles continue to inhibit women's career development in the workplace (Tower \& Alkadry, 2008). Women working in the upper managerial levels occupy a relatively small proportion of the workforce in most countries (Adler, 1993; Burke, 2005). The majority of decision-making positions in government are still dominated by men (Guy, 1983). South Korea is not an exception to this phenomenon. Despite the increasing prevalence of women in the public sector, the representation of women officials in the managerial grade levels remains low relative to other countries that have joined OECD (Bae, Kim, \& Kim, 2000; OECD, 2003). In 2013, women at the managerial levels occupied only 8.7 percent of positions in the Korean central government (MOSPA, 2014).

A considerable number of studies have investigated the question of why the proportion of women in the top managerial levels has remained relatively small, but many of those studies have discussed this issue using the concept of job segregation, the glass ceiling, and pay equity during women's integration process into the workforce (Tower \& Alkadry, 2008). To offer another approach, this article deals with women who have managed to break through the barriers and constraints women continue to face. That is, this article is interested in what factors affect career success of women and what core competencies distinguish those successful women. Considering that it takes time to reform the existing human resources system dramatically, it might be meaningful to investigate the competencies of successful women who have already overcome existing barriers or ceilings in the public sector. The lessons from those women may provide real insights for women employees beginning their careers to establish the career model for the future. Although researchers have become increasingly interested in the characteristics of successful career women since the mid-1990s (Kirchmeyer, 1998; Northcutt, 1991), prior research on the determinants of factors of women's career success centered mainly on either the workforce in the private sector or took a case study approach for individual women. Therefore, this article tests empirically what factors contribute to more successful careers for Korean women in the public sector. Specifically, two main goals are explored in this study: (1) to investigate the factors affecting career success of women in the public sector and (2) to assess the relative importance of personal factors and situational factors for women's career success. 
The present study is organized as follows. The first part examines the theoretical explanations concerning the concept of career success and determinants for women's career success. The second part deals with the research methods, and the next section shows the data analyses and results. Finally, the implications of the findings and future directions are discussed.

\section{Literature Review}

Scholars have defined and developed the concept of career success as "the positive work-related outcomes or achievement one has accumulated as a result of one's work experience" (Judge \& Bretz, 1994; Judge et al., 1995). Two types of career success have discussed in the literature: objective and subjective career success (Callanan, 2003; Crozier, 1999). While objective career success refers to objectively observable achievements that can be measured, such as salary, promotion, and status (Jaskolka, Beyer, \& Trice, 1985; Judge et al., 1995; Seibert, Kraimer, \& Liden, 2001; Wayne et al., 1999), subjective career success has been defined as an individual's feeling of accomplishment and satisfaction with his or her career (Judge et al., 1995; Wayne et al., 1999).

Early research in this area focused on determinants of objective career success, and rarely measured career satisfaction. As the argument that many people who have managerial careers (they are extrinsically successful) are not satisfied with their achievements finds support in the later literature (Korman, Wittig-Berman, \& Lang, 1981), however, research has moved towards the use of a set of objective and subjective evaluations of career success (e.g., Gattiker \& Larwood, 1988; 1990; Jaskolka, Beyer, \& Trice, 1985; Judge \& Bretz, 1994; Judge et al., 1995; Kirchmeyer, 1998; Melamed, 1996; Tharenou \& Conroy, 1994). Thus, this article uses a comprehensive approach that examines both objective and subjective career success.

Criteria for categorizing the factors to explain career success have varied widely (e.g., Fagenson, 1990; Gattiker \& Larwood, 1988; Jaskolka, Beyer, \& Trice, 1985; Tharenou \& Conroy, 1994; Tharenou, Latimer, \& Conroy, 1994). The present research selects a personal-situational approach, based on Fagenson (1990) and Tharenou and Conroy (1994). Concrete factors used in this article are derived from other research offering theoretical and empirical insights into women's career success. The predictors are classified into two sets: 1) personal factors, that include personality, demographic characteristics, and motivation, and 2) situational factors, that include work environment and home environment variables.

\subsection{Personal Factors}

\subsubsection{Personality}

Although the argument that personality affects career success at the managerial level has long existed, researchers did not begin to examine the relationship until after the mid-1990s (Seibert, Kraimer, \& Liden, 2001). They focused on diverse aspects of personality, not on a single personality trait. For example, Judge and colleagues (1999) and Seibert and colleagues (2001) examined the relationship between overall personality framework and career success using the Big Five Factor model of personality. Goldberg (1990) suggested the Big Five Factor model, which refers to the five major dimensions of personality: neuroticism, extraversion, openness, agreeableness, and conscientiousness. Neuroticism involves "the tendency to exhibit poor emotional adjustment and experience negative affect, including anxiety, depression, hostility, impulsiveness, self-consciousness, and vulnerability." Extraversion involves "the tendency to be sociable, assertive, and experience positive affect, including warmth, gregariousness, excitement seeking." Openness is "the disposition to be imaginative, unconventional, and autonomous." Agreeableness is "the tendency to be trusting, compliant, caring, and gentle." Conscientiousness includes "achievement striving, competence, deliberation, dutifulness, order, and self-discipline" (Boudreau \& Boswell, 2001; Costa \& McRae, 1992; White et al., 2004). Previous studies concerning personal characteristics have used these variables as a basic framework. In the literature, depending on empirical contexts, the types of personality influencing career success varied. Although there is research evidence showing three of the Big Five factors (neuroticism, extraversion, and conscientiousness) are influential factors in career success (Judge et al., 1999), the research findings have shown mixed results. Although some research found that neuroticism was negatively related to job satisfaction (e.g., Tokar \& Subich, 1997; Seibert et al., 2001), Judge and colleagues (1999) argued there was no significant relationship between them. Extraversion was positively related to both objective and subjective career success (e.g., Tokar \& Subich, 1997; Seibert et al., 1999; Judge et al., 1999). Thus, this needs to be clarified in future research.

\subsubsection{Demographic Characteristics: Age, Education Level, Work Experience}

Regarding the effect of age on career success, the research does not show consistent findings. For example, Gattiker and Lawwood (1988), Jaskolka and colleagues (1985), and Judge and colleagues (1995) argued that age 
has a consistent relation with managerial level and salary; on the other hand, Tharenou and Conroy (1994) did not find a significant relation between age and managerial level. Cox and Harguail (1991) pointed out that age was positively related to salary, but it had a negative effect on subjective career success.

Education level is one of the demographic characteristics considered by previous studies of career success and is a strong predictor of managerial level, salary, and promotion (Cox \& Harquil, 1991; Jaskolka, Beyer, \& Trice, 1985). Drawing on Melamed's (1995b) research findings, education level was positively related to salary and managerial level. Tharenou and Conroy (1994) also found a positive relationship between education level and objective career success. They explained that education provided knowledge or skills to carry out duties in higher ranks. Stewart and Gudykunst (1982) found the same result for the relationship of education and managerial level; however, they also reported that education level, especially for females, had a negative relationship with number of promotions.

Work experience has been viewed as another strong predictor of career success; this relationship was observed for both men and women at the managerial level (Tharenou \& Conroy, 1994). Work experience was related positively to objective career success, such as pay and promotion (e.g., Cox \& Harquil, 1991; Dreher \& Ash, 1990; Whitely, Dougherty, \& Dreher, 1991). Although Gattiker and Larwood (1988) found no significant relation between years of work experience and managerial level, they did find that years of work experience had a negative effect on career satisfaction.

\subsubsection{Motivation}

According to Vroom's expectancy theory of motivation, "people are motivated to put forth effort if they expect that the effort will lead to good performance, and that the effort will be instrumental in attaining valued outcomes" (Wayne et al., 1999). Researchers have tried to apply this theory to predict career success by incorporating motivation factors in their analytical framework. For example, Whitely and colleagues (1991) tested two variables-average number of hours worked per week and expected future income- to measure work motivation and found a positive relationship between these variables and compensation. Judge and Bretz (1994) also reported that the number of hours worked per week was positively related to salary. On the other hand, in Wayne and colleagues' (1991) findings, the desire for mobility was negatively related to career satisfaction even though it was positively related to salary and promotion.

\subsection{Situational Factors}

\subsubsection{Work Environment: Training, Mentoring, Informal Network, and Gender Bias}

The first set of situational factors is the work environment. Training helps improve managerial skills and competencies, especially for female managers, because women usually have fewer opportunities than men to gain managerial skills through work experience (Tharenou \& Conroy, 1994; Tharenou, Latimer, \& Conroy, 1994). Tharenou and colleagues (1994) provided evidence that education increases knowledge, skills, and credibility for performance in top executive positions.

Scholars agree that mentors play a significant role in advancing women and men up their career ladders (Newman, 1993; Kirchmeyer, 1998). A mentor is generally defined as "a higher-ranking, influential individual in your work environment who has advanced experience and knowledge and is committed to providing upward mobility and support in your career" (Ragins, 1989) and a supervisor's attitude as a mentor is one of the strongest variables affecting career success (Adler, 1993; Greenhaus et al. 1990). Wayne and colleagues (1999) criticized prior research that did not include mentoring as a variable. They found significant relationships only for promotion, whereas for salary and career satisfaction, there was no significant effect. Tharenou et al. (1994) argued that employees who were supported by supervisors or peers were more satisfied with their organizations, and further, this support positively affected their job performance.

Engagement in an informal network has been considered as another factor that affects women's career success. Most organizations have many informal networks where members share their social interests, such as sports. Discussion and decisions on organizational issues often take place in informal, rather than formal structures. Men easily join these "clubs" or "old boy networks" (Perrewe \& Nelson, 2004). Participation in these informal networks gives them chances to build trust and bonding among men and they may receive valuable resources and support with inclusion in such networks (Brass, 1985). However, women tend to be excluded from these informal networks. Research indicated that women do not benefit from informal networks as much as their male colleagues do (Hetty van Emmerik, Euwema, Geschiere, \& Schouten, 2006). Canning and Montmarquette (1991) indicated that, depending on gender, informal networks have different impacts on the number of promotions, such that exclusion from informal networks works to the disadvantage of women managers. 
Gender bias influencing career success has a strong root in our cultural, educational, and legal system (Adler 1993). Studies on attribution theory showed that a male manager's success can be explained differently from a female manager's success. Individual competencies such as leadership and responsibility are perceived as important factors for men's success, while women's success depends on luck or external factors, such as affirmative action (Heilmen, 1983; Schein, 1978). Because there exists a gender bias that men are more 'appropriate' for managerial positions than women, women managers should demonstrate masculine tendencies and are not expected to 'act feminine' for their career success. As a result, gender bias excludes women from career advancement.

\subsubsection{Home Environment}

Home environment involves marital status, number of children, and spouse/family support. These factors are known to play important roles in women's career success. Much of women's career success literature found that women experienced considerable role conflicts and had more career interruptions from family demands, such as raising children and domestic work (Kirchmeyer, 1998; Noonan, 2001). A substantial percentage of women are constrained in their career advancement by domestic work or family obligations (Johnson \& Duerst-Lahti, 1992). Despite women's participation rate into the workforce increasing dramatically, domestic work continues to be done mainly by women (Noonan, 2001). They face balancing domestic responsibilities with good performance in the workplace (Guy, 2003).

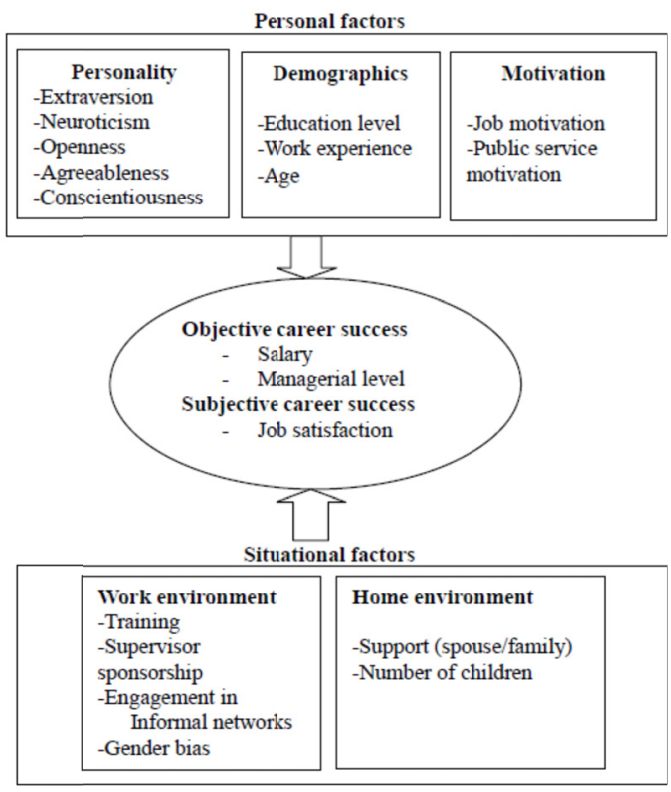

Figure 1. Research model of career success

Marital status has a strong effect on women's promotions, regardless of equal opportunity legislation (Adler, 1993; Melamed, 1995b). White and Cooper (1994) described delayed marriage and a smaller number of children as characteristics of women in higher level positions (as cited in Melamed, 1995a). By the same token, female managers are more likely to be single and have fewer children than male managers (Gutek, 1988; Tharenou \& Conroy, 1994; Vertz, 1985), and they also "experience higher divorce rates than men" (Frisco \& Williams, 2003). Vertz (1985) found that spousal support plays a significant role in women's career success. Women in advanced positions perceive their spouses as viewing their work as more important than do women in lower-level positions (Vertz, 1985). In contrast to these points of view, some empirical research concluded that home situations, such as marital status or spouse support, had little or no relative importance for job level compared with other factors (Dreher \& Ash, 1990; Judge \& Bretz, 1994; Judge, Cable, Boudreau, \& Bretz, 1995; Melamed, 1996; Tharenou \& Conroy, 1994; Whitely, Dougherty, \& Dreher, 1991). The present study investigated several important factors that lead to women's career success. Based on these considerations, the following hypotheses were developed.

H1: Situational factors will have stronger effects on women's objective career success than personal factors.

1-1: Situational factors will have stronger effects on women's salary than personal factors.

1-2: Situational factors will have stronger effects on women's managerial levels than personal factors. 
H2: Situational factors will have stronger effects on women's subjective career success (i.e., job satisfaction) than personal factors.

Figure 1 shows the analytical framework of career success. The specific variables were hypothesized in terms of several categories. Consistent with Jaskolka, Beyer, and Trice (1985) and Melamed (1995a; 1995b), objective career success was measured with two indicators: salary and job level. Subjective career success was conceptualized as job satisfaction.

\section{Research Methods}

\subsection{Samples and Procedures}

This study was conducted using a survey research design in 18 Korean Ministries. Korean civil servants are divided into "career" and "special career (non-career)" civil servants. "Career" civil servants include three service categories: general, special and technical services. General Service represents administrative occupations and it can be classified into nine grades from the highest grade 1 to the lowest grade 9 (Kim, 1997). In this study, survey data was collected from female public officials at the managerial level (grade 1 through grade 5) in general service.

Table 1. The classification of general service

\begin{tabular}{llllll}
\hline Grade 1 & Grade 2 & Grade 3 & Grade 4 & Grade 5 & Grade 6-9 \\
\hline Assistant & Director & Director & Director & Deputy & Officer \\
Minister & (General) & (Bureau) & (Division) & Director & Staff \\
\hline
\end{tabular}

Source. Kim (1997)

A convenience sample of 130 female public officials was drawn from employees who were working at a government building in the Central and Gwacheon government complexes (Appendix presents female public officials at the managerial level (grades 1 to 5)). Additionally, I limited subjects to those public employees who had served more than 5 years to ensure those employees had enough work experience to assess their level of career success in the organization (Wanye, Liden, Kraimer, \& Graf, 1999). For collecting data, anonymous questionnaires were distributed to 130 female public officials in November, 2004. To increase response rates, I directly visited each department at the government buildings in Seoul (Central) and Gwacheon. Before distributing questionnaires, I explained the goals of the study to respondents and answered questions. Although a total of 110 questionnaires were returned (84.6\% response rate), I eliminated questionnaires that showed either a central tendency or whose years of work experience were less than 5 years. Thus, the final response rate was 69.2 percent (90 questionnaires in total). Table 2 shows descriptive statistics of the variables.

Table 2. Descriptive statistics

\begin{tabular}{lccccc}
\hline \multicolumn{1}{c}{ Variable } & Obs & Mean & Std. Dev. & Min & Max \\
\hline Age & 90 & 37.94 & 7.58 & 26 & 56 \\
Education & 81 & 4.52 & 0.63 & 1 & 5 \\
Yrs of work experience & 90 & 11.78 & 8.43 & 3 & 31 \\
\hline Training & 83 & 5.78 & 6.58 & 0 & 45 \\
Supervisor sponsorship & 90 & 3.48 & 0.72 & 1 & 4.5 \\
Informal network & 90 & 3.28 & 0.67 & 1.33 & 5 \\
Gender bias & 89 & 2.97 & 0.67 & 1.8 & 5 \\
\hline Job motivation & 81 & 2.98 & 0.69 & 1 & 4.75 \\
Public service motivation & 89 & 3.75 & 0.57 & 2.25 & 5 \\
\hline Spouse/family support & 64 & 53.14 & 25.36 & 0 & 100 \\
\# of children & 61 & 1.31 & 0.79 & 0 & 3 \\
\hline Neuroticism & 90 & 3.23 & 0.73 & 1 & 5 \\
Extraversion & 90 & 3.61 & 0.62 & 2.33 & 5 \\
Conscientiousness & 90 & 3.89 & 0.66 & 3 & 5 \\
Openness & 90 & 3.49 & 0.81 & 2 & 5 \\
\hline Salary & 89 & 2.18 & 1.06 & 1 & 5 \\
Managerial level & 90 & 4.69 & 0.55 & 3 & 5 \\
Job satisfaction & 3.23 & 0.51 & 1.64 & 4.71 \\
\hline
\end{tabular}


Cronbach's $\alpha$ was used to test the reliability of the questionnaire, and a principal component factor analysis with Varimax rotation was conducted to test construct validity of independent variables. Through this process, an incorrectly classified variable (agreeableness) was deleted.

\subsection{Measures}

Variables in the survey were measured using single open-ended questions or single closed response type questions with five-point scales ranging from "strongly disagree" to "strongly agree."

\subsubsection{Objective Career Success}

Consistent with Jaskolka, Beyer, and Trice (1985) and Melamed (1995a; 1995b), objective career success was measured with two indicators: salary and managerial level. Salary was measured by asking respondents to report annual salary including allowances. Responses were placed in the following categories: $1=$ less than 30 million won $^{1}, 2=30$ million-less than 40 million won, $3=40$ million won-less than 50 million won, $4=50$ million-less than 60 million won, $5=$ over 60 million won.

\subsubsection{Subjective Career Success}

This indicator was conceptualized as job satisfaction. Job satisfaction has been defined as "a positive emotional state resulting from an appraisal of one's job" (Judge, Cable, Boudreau \& Bretz, 1995). Job satisfaction was measured with 14 items from a Korean manual for government organization diagnosis ${ }^{2}$. Job satisfaction measurement in the manual consisted of "motivator factors" and "hygiene factors," based on Herzberg's theory. Motivator factors involved compensation, welfare, promotion, and work environment. Hygiene factors involved position and duty, autonomy and achievement by work. Items were evaluated on a 5-point scale with response categories ranging from 1 (strongly unsatisfied) to 5 (strongly satisfied).

\subsubsection{Demographic Variables}

Education level, age, and years of work experience were measured with single items. The item for measuring education level was "What is your highest educational level?" Response categories were as follows: less than high school diploma, high school diploma, 2-year college degree, 4-year undergraduate degree, master's degree, and Ph.D. degree.

\subsubsection{Personality}

To measure personality concepts, this article used Goldberg's (1990) Big Five Factor structure, which describes personality as a composition of five factors: neuroticism, extraversion, openness (to experience), agreeableness, and conscientiousness. In this study, a total of 15 items (three items for each trait) were chosen from the Korean version of NEO PI-R (Personally Inventory-Revised), which is a self-reported instrument with 240 items measuring the five factors ${ }^{3}$. Examples of items are "I emphasize being with others; gregarious (extraversion)," and "I tend to arouse liking and acceptance from others (agreeableness)."

\subsubsection{Motivation}

Motivation variables include job motivation and public service motivation. To measure these items, previous studies usually tested two indicators such as "hours worked per week" and "desire for upward mobility" (Judge \& Bretz, 1994; Wayne, Liden, Kraimer, \& Graf, 1999). However, in the present study, job motivation was measured with eight items from a Korean manual for government organization diagnosis (PCGID, 2004) because I expected these items reflected both the uniqueness of the public organization and culture in Korea. The manual used the adapted Situational Motivation Scale (SIMS) (See Guay, Vallerand and Blanchard's (2000) article to get more information about SIMS to measure job motivation. In detail, they assessed intrinsic motivation, external motivation and amotivation). Examples are "I think that this activity is interesting," and "I do this activity but I am not sure if it is worth it." Public service motivation (PSM) was also measured because public employees were the subjects of this study. I asked six questions drawn from Perry's (1996) work using a five-point scale. Items included "I feel people should give back to society more than they get from it," and "I unselfishly contribute to my community."

\subsubsection{Work Environment}

This category encompassed four variables. First, training time was measured in days per year. It consists of two items: time on internal training courses and time on external training courses. The second indicator was supervisor sponsorship, which was measured with six items from Wayne et al. (1999). Example items are "my supervisor has encouraged me to try new ways of behaving in my job," and "my supervisor has enough confidence in me that he/she would defend and justify my decisions even if I was not present to do so." Engagement in informal networks and perceived gender bias were also measured using a five-point scale. 


\subsubsection{Home Environment}

Three measures of home environment were used: spouse/family support and the number of children. Number of children was measured with single item. Spouse/family support was measured by asking respondents the percentage of domestic duties performed by spouse or family. This question was based on Tharenou and Conroy's (1994) study.

\section{Data Analysis and Results}

Hierarchical multiple regression analyses were conducted to examine statistical explanatory power and the significance of the five groups of independent variables. Through these processes, I analyzed goodness of fit, obtained the degree to which each group of independent variables explained dependent variables, and outlined the relative contribution of independent variables in predicting career success. Often, some of the independent variables are very highly interrelated in a multiple regression model (i.e., multicollinearity). Through checking the variation inflation factor (VIF), I confirmed that multicollinearity was not a problem in the present analyses.

The analyses were conducted at two levels: (1) the impact of variables on career success was assessed, and (2) the relative importance of personal and situational factors in predicting women's career success was estimated. In hierarchical multiple regression, a researcher might decide the entering order of each predictor set based on theoretical or empirical grounds. In the present study, regression analyses, comprising five steps, were run for each dependent variable to test for the incremental variances added by predictor sets. Independent variables were entered sequentially; demographical indicators were entered in step 1, work environment indicators in step 2, motivational indicators in step 3, home environment indicators in step 4, and personality traits in step 5.

Table 3. Hierarchical regression analyses on the determinants of career success

\begin{tabular}{|c|c|c|c|}
\hline Variable & $\begin{array}{c}\text { Salary } \\
\beta\end{array}$ & $\begin{array}{c}\text { Managerial level } \\
\beta \\
\end{array}$ & $\begin{array}{c}\text { Job satisfaction } \\
\beta \\
\end{array}$ \\
\hline \multicolumn{4}{|l|}{ Step1: Demographics } \\
\hline Age & $.637 * * *$ & $.795^{* * *}$ & .040 \\
\hline Education level & .022 & .180 & -.148 \\
\hline Years of work experience & .142 & .186 & .289 \\
\hline Change in $R^{2}$ & .593 & .273 & .203 \\
\hline \multicolumn{4}{|l|}{ Step2: Work environment } \\
\hline Training & $-.164 *$ & .095 & .054 \\
\hline Supervisor sponsorship & $.193^{*}$ & $.352 * *$ & $.269^{*}$ \\
\hline Informal network & .055 & .212 & .144 \\
\hline Gender bias & .022 & .121 & .001 \\
\hline Change in $R^{2}$ & .045 & .011 & .233 \\
\hline \multicolumn{4}{|l|}{ Step3: Motivation } \\
\hline Job motivation & $.191^{*}$ & $.385^{* * *}$ & .132 \\
\hline Public service motivation & -.143 & .166 & -.072 \\
\hline Change in $R^{2}$ & .028 & .093 & .007 \\
\hline \multicolumn{4}{|l|}{ Step4: Home environment } \\
\hline Spouse/family support & .039 & -.173 & $.321 * * *$ \\
\hline Number of children & -.056 & .303 & .073 \\
\hline Change in $R^{2}$ & .002 & .045 & .066 \\
\hline \multicolumn{4}{|l|}{ Step5: Personality } \\
\hline Neuroticism & $-.231 *$ & $-.373 * *$ & .192 \\
\hline Extraversion & -.027 & .065 & .059 \\
\hline Conscientiousness & .110 & $.364 * *$ & .020 \\
\hline Openness & .122 & $-.470 * *$ & .141 \\
\hline Change in $R^{2}$ & .033 & .163 & .050 \\
\hline Final $R^{2}$ & .702 & .584 & .559 \\
\hline Adjusted $R^{2}$ & .590 & .428 & .389 \\
\hline Overall $F$ & $6.268 * * *$ & $3.749 * * *$ & $3.296 * * *$ \\
\hline
\end{tabular}

Notes. a. Based on the result of the factor analysis, item for measuring "agreeableness" was dropped due to poor loadings. $b$. $\beta=$ standardized coefficient 
The results of three hierarchical regression models predicting career success are shown in Table 3 . In this research, when five blocks of independent variables were entered sequentially, the increase of $R^{2}$ in each step for dependent variables reached statistical significance. In a hierarchical regression analysis, the significant incremental variance of each predictor set means that each predictor set explains the amount of variance for each dependent variable. For example, when work environment variables were entered as a block, the incremental variance of the predictor set was 4.5 percent $\left(\Delta R^{2}=0.045, \mathrm{p}<0.01\right)$ for salary. That means work environment variables accounted for a 4.5 percent increase in the variance explained in the salary.

The first column in Table 3 shows the relative contribution of the predictor sets in predicting salary. The variance explained by each predictor set suggested that Hypothesis 1-1 was not supported. Personal factors including demographics $\left(\Delta R^{2}=0.593, \mathrm{p}<0.01\right)$, motivation $\left(\Delta R^{2}=0.028, \mathrm{p}<0.01\right)$, and personality $\left(\Delta R^{2}=\right.$ $0.033, \mathrm{p}<0.01)$ explained larger amounts of variation in salary than situational factors, including work environment $\left(\Delta R^{2}=0.045, \mathrm{p}<0.01\right)$ and home environment $\left(\Delta R^{2}=0.002, \mathrm{p}<0.01\right)$. The results also indicated that the five variables had a significant impact on salary. I examined the standardized coefficients to assess the relative contribution of the independent variables in predicting salary. The relative order of the variables and beta weights for each variable were as follows: age (0.637), neuroticism (-0.231), supervisor sponsorship (0.193), job motivation (0.191), and training (-0.164).

Hypothesis 1-2 predicted that situational factors were more associated with women's managerial levels than personal factors. The second column in Table 3 presents the incremental variances explained in the managerial level. According to Table 3, personal factors explained the most variation in estimating managerial level. Thus Hypothesis 1-2 was not supported. Additionally, a comparison of the standardized coefficients showed that seven variables followed a relative order of contribution in predicting managerial level: age (0.795), openness $(-0.470)$, job motivation $(0.385)$, neuroticism $(-0.373)$, conscientiousness $(0.364)$, and supervisor sponsorship $(0.352)$.

Hypothesis 2 predicted that situational factors were more associated with women's subjective careers than personal factors. As stated previously, job satisfaction indicators were used in measuring subjective career success. The increase of $R^{2}$ by each predictor set was as follows: work environment $\left(\Delta R^{2}=0.233, \mathrm{p}<0.01\right)$, demographics $\left(\Delta R^{2}=0.203, \mathrm{p}<0.01\right)$, home environment $\left(\Delta R^{2}=0.066, \mathrm{p}<0.01\right)$, personality $\left(\Delta R^{2}=0.05, \mathrm{p}<\right.$ $0.01)$, and motivation $\left(\Delta R^{2}=0.007, \mathrm{p}<0.01\right)$. Work environment had one of the strongest effects as a situational factor (but not the situational factor as a whole) and demographics were second. The $R^{2}$ aggregation of situational factors $(0.299)$ was bigger than that of personal factors $(0.260)$. Thus, overall, Hypothesis 2 was supported by the results.

\section{Discussion and Conclusions}

The results of the regression analyses revealed the following findings.

First, the study assessed the relative importance of personal and situational factors in explaining women's career success. The results showed that although personal factors had stronger effects on objective career success than situational factors, situational factors had stronger effects on subjective career success than personal factors. These findings differ from those of Tharenou and Conroy (1994), who argued that situational factors explained women's objective career success better than personal traits. While work environment indicators were the strongest determinant of objective career success in their research, the present research showed demographic variables, especially age, strongly predicted Korean women's objective career success in the public sector. The positive relationship of age and salary (or managerial level), naturally results because the Korean government organization (including a classification of civil servants and most personnel management) is still saturated with the factors of a rank system (Yoo \& Yim, 2004). Although the Korean government begun to adopt an "open career system" in terms of introduction of competition into the civil service, the result of the study suggests effects of that reform, such as a breakdown of grade-based promotion, have yet to be seen.

Second, the analyses in the study demonstrated the impact of variables on objective career success. The specific findings related to objective career success demonstrated that the following determinants: age, supervisor sponsorship, job motivation and neuroticism, remained commonly significant predictors of objective career success. Home environment was not significantly associated with objective career success. However, the result showed that single women beyond their 30s represented 73 percent of unmarried respondents. In the case of women 35 or older, 15 respondents had no child. This finding, to some degree, appears to support earlier arguments that marriage and parenthood hinder women's careers (Betz \& Fitzgerald, 1987; Melamed, 1995a).

Contrary to my expectation, training had a negative relationship with salary. This result reflects the reality that training programs do not provide well for women at the managerial level in Korea. According to statistics about 
training for female public officials, 16 training programs in 14 organizations were conducted for female public officials in 2003. However, there were few programs for women at "top" managerial levels because the target of most programs was confined to women at grade five or under (MOGAHA, 2003).

Age, supervisor sponsorship, job motivation, neuroticism, openness, and conscientiousness explained significant amounts of variance at the managerial level. Age was the best predictor of both salary and managerial level. Openness was negative for managerial level, which means female public officials who had more openness remained in lower managerial levels. This result was not consistent with earlier research. Seibert and Kraimer (2001) failed to find a significant relationship between openness and career success (number of promotions and career satisfaction). Eby et al. (2003) found significant effects only between openness and perceived career success. One explanation is that the subjects of this study differed from those in previous research. Although earlier research selected firm managers in Western countries, the subjects in this study were public officials in the Korean central government. This finding may reflect the Korean central government's conservative culture. Thus, additional future research is needed to examine differences of career success determinants between the public and private sector and to consider the role of national culture.

Finally, two significant results (supervisor sponsorship and spouse/family support) were found with job satisfaction, an indicator of subjective career success. Both variables were positively associated with subjective career success. Consistent with Kirchmeyer's (1998) study, this result suggests that fewer domestic duties at home had positive effects on women's job satisfaction. As a result, spouse/family support was a significant factor, not on objective career success, but on subjective career success. This consequence can be supported by Gilligan's (1993) argument. She explained that "for men, the positive impact of family variables on objective career success should translate into positive perceptions of career success. Women's perceptions of success also may be affected positively by these variables even if their objective success is affected negatively. For women, the accomplishments and rewards from family life may be integrated into a broad view of career success."

The findings and implications of this study should be interpreted with its limitations borne in mind. As a limitation, this study has potential sampling bias, coming from a convenience sampling method. I limited subjects to female public officials at the managerial level (grade one through grade five) in general service, who worked in the Central and Gwacheon complexes, and who also had served more than 5 years. Thus, the results can be generalized only on a limited basis. Also, because the data used in the analyses were gathered from self-reports, there is the possible risk of common method bias, which is caused by "measuring the dependent and independent variable at the same time by the same person and with the same instrument, without any possibility for cross-verification" (Willem \& Buelens, 2007).

Despite these limitations, the current study has several implications. First, by attempting to merge many of the relevant variables in previous studies, this study provides relatively comprehensive evidence regarding the predictors of women's career success. It is suggestive especially for South Korea, because most studies about female public officials have focused on the decrease of gender biases or glass ceilings; therefore, career success in the public sector remains under-researched in South Korea.

Second, this study can contribute to the development of a women's career management model by empirically analyzing determinants predicting career success of women managers. Suggesting the criteria for women's career success is an important step for the development of a new career model (Kirchmeyer, 1998), but prior career success studies have concentrated mainly on developing career success models for men. In a sense, this study suggests a guide for those who make decisions about women's careers in the public sector and it also provides career preparation strategies for women in the public sector.

Expanding our model to include a broader array of individual factors such as individual strategies or management behaviors would be a worthwhile endeavor in future research. For example, related research examining women career development has shown that leadership and family balance strategies can influence career advancement. Future research could also consider specific career paths of women public officials who achieve career success. It may identify possible career patterns for career advancement and illustrate other organizational resources that have the potential to affect female public officials' career success.

\section{References}

Adler, N. J. (1993). An International Perspective on the Barriers to the Advancement of Women Managers. Applied Psychology: An International Review, 42(4), 289-300. http://dx.doi.org/10.1111/j.1464-0597. 1993.tb00745.x

Bae, D.-J., Kim, P.-S., \& Kim, Y.-M. (2000). Target-Base Human Resource Management by Agency for 
Promoting Employment of Higher-Level Women in Government. Korean Journal of Public Administration, 34(1), 137-158.

Betz, N. E., \& Fitzgerald, L. F. (1987). The Career Psychology of Women. New York: Wiley.

Boudreau, J. W., \& Boswell, W. R. (2001). Effects of Personality on Executive Career Success in the United States and Europe. Journal of Vocational Behavior, 58, 53-81. http://dx.doi.org/ 10.1006/jvbe.2000.1755

Brass, D. J. (1985). Men's and women's networks: A study of interaction patterns and influence in an organization. Academy of Management journal, 28(2), 327-343. http://dx.doi.org/10.2307/256204

Burke, R. J. (2005). High-Achieving Women: Progress and Challenges. In R. J. Burke, \& M. C. Mattis (Eds.), Supporting Women's Career Advancement: Challenges and Opportunities (pp. 13-30). MA: Edward Elgar Publishing.

Callanan, G. A. (2003). What Price Career Success? Career Development International, 8(3), $126-133$. http://dx.doi.org/10.1108/13620430310471032

Cannings, K., \& Montmarquette, C. (1991). Managerial momentum: a simultaneous model of the career progress of male and female managers. Industrial \& Labor Relations Review, 44(2), 212-228.

Costa, P. T., \& McRae, R. R. (1992). Revised NEO Personality Inventory (NEO-PI-R) and NEO Five-Factor Inventory (NEO-FFI) Professional Manual. Odessa: FL: Psychological Assessment Resources.

Cox, T. H., \& Harquil, C. V. (1991). Career Paths and Career in the Early Career Stages of Male and Female MBAs. Journal of Vocational Behavior, 39, 54-75. http://dx.doi.org/10.1016/0001-8791(91)90004-6

Crozier, S. D. (1999). Women's Career Development in a 'Relational Context'. International Journal for Advancement of Counseling, 21, 231-247. http://dx.doi.org/10.1023/A:1005489823722

Dreher, G. F., \& Ash, R. A. (1990). A Comparative Study of Mentoring Among Men and Women in Managerial, Professional and Technical Positions. Journal of Applied Psychology, 75(5), 539-546. http://dx.doi.org/10.1037/0021-9010.75.5.539

Eby, L. T., Butts, M., \& Lockwood, A. (2003). Predictors of Success in the Era of the Boundaryless Career. Journal of Organizational Behavior, 24,689-703. http://dx.doi.org/10.1002/job.214

Fagenson, E. A. (1990). At the Heart of Women in Management Research. Journal of Business Ethics, 9, 1-8. http://dx.doi.org/10.1007/BF00380326

Frisco, M. L., \& Williams, K. (2003). Perceived housework equity, marital happiness, and divorce in dual-earner households. Journal of Family Issues, 24(1), 51-73.

Gattiker, U. E., \& Larwood, L. (1988). Predictors for Managers' Career Mobility, Success, and Satisfaction. Human Relations, 41(8), 569-591. http://dx.doi.org/10.1177/001872678804100801

Gilligan, C. (1983). In a Different Voice: Psychological Theory and Women's Development. Cambridge, Massachusetts: Harvard University Press. http://dx.doi.org/10.1016/0091-2182(83)90042-3

Goldberg, L. R. (1990). An Alternative Description of Personality: The Big Five Factor Structure. Journal of Personality and Social Psychology, 15, 557-564. http://dx.doi.org/10.1037/0022-3514.59.6.1216

Greenhaus, J. H., Parasuraman, S., \& Wormley, W. M. (1990). Effects of Race on Organizational Experiences, Job Performance Evaluations, and Career Outcomes. Academy of Management Journal, 33, 64-86. http://dx.doi.org/10.2307/256352

Guay, F., Vallerand, R. J., \& Blanchard, C. (2000). On the Assessment of Situational Intrinsic and Extrinsic Motivation: The Situational Motivation Scale (SIMS). Motivation and Emotion, 24(3), 175-213. http://dx.doi.org/10.1023/A:1005614228250

Gutek, B. A. (1988). Sex Segregation and Women at Work. Applied psychology: An International Review, 37, 10-27. http://dx.doi.org/10.1111/j.1464-0597.1988.tb01130.x

Guy, M. E. (1993). Three Steps Forward, Two Steps Backward: The Status of Women's Integration into Public Management. Public Administration Review, 53(4), 285-292.

Anonymous. (2003). The difference that gender makes. Public personnel administration: Problems and prospects, 265-269.

Heilman, M. E. (1983). Sex bias in work settings: The Lack of Fit model. Research in organizational behavior.

Hetty van Emmerik, I. J., Euwema, M. C., Geschiere, M., \& Schouten, M. F. (2006). Networking your way 
through the organization: gender differences in the relationship between network participation and career satisfaction. Women in Management Review, 21(1), 54-66.

Jaskolka, G., Beyer, J. M., \& Trice, H. M. (1985). Measuring and Predicting Managerial Success. Journal of Vocational Behavior, 26(2), 189-205. http://dx.doi.org/10.1016/0001-8791(85)90018-1

Johnson, C. M., \& Duerst-Lahti, G. (1992). Public work, private lives. Women and men of the states: Public administrators at the state level, 61-88.

Judge, T. A., \& Bretz, R. D. (1994). Political Influence Behavior and Career Success. Journal of Management, 20(1), 43-65. http://dx.doi.org/10.1177/014920639402000103

Judge, T. A., Cable, D. M., Boudreau, J. W., \& Bretz, R. D. (1995). An Empirical Investigation of the Predictors of Executive Career Success. Personnel Psychology, 48, 485-519. http://dx.doi.org/10.1111/j.1744-6570. 1995.tb01767.x

Judge, T. A., Higgins, C. A., Thoresen, C. J., \& Barrick, M. R. (1999). The Big Five Personality Traits, General Mental Ability, and Career Success across the Life Span. Personnel Psychology, 52(3), 621-652. http://dx.doi.org/10.1111/j.1744-6570.1999.tb00174.x

Kim, Y.-P. (1997). The Korean Civil Service System. Paper presented at the Civil Service Systems in Comparative Perspective. Bloomington, Indiana, April 5-8.

Kirchmeyer, C. (1998). Determinants of Managerial Career Success: Evidence and Explanation of Male/Female Difference. Journal of Management, 24(6), 673-692. http://dx.doi.org/10.1177/014920639802400601

Korman, A. K., Wittig-Berman, U., \& Lang, D. (1981). Career Success and Personal Failure: Alienation in Professionals and Managers. Academy of Management Journal, 24(2), 342-360. http://dx.doi.org/10.2307/ 255846

Melamed, T. (1995a). Barriers to Women's Career Success: Human Capital, Career Choices, Structural Determinants, or Simply Sex Discrimination. Applied psychology: an international review, 44(4), 295-314. http://dx.doi.org/10.1111/j.1464-0597.1995.tb01082.x

Melamed, T., (1995b). Career Success: The Moderating Effect of Gender. Journal of Vocational Behavior, 47, 35-60. http://dx.doi.org/10.1006/jvbe.1995.1028

Melamed, T. (1996). Career Success: An Assessment of a Gender-Specific Model. Journal of Occupational and Organizational Psychology, 69, 217-242. http://dx.doi.org/10.1111/j.2044-8325.1996.tb00612.x

Ministry of Government Administration and Home Affairs (MOGAHA). (2003). Women and Public Service.

Ministry of Security and Public Administration (MOSPA). (2014). Report on the Employment of the Government. Seoul: MOSPA.

Newman, M. A. (1993). Career Advancement: Does Gender Make a Difference? American Review of Public Administration, 23(4), 361-384. http://dx.doi.org/10.1177/027507409302300404

Noonan, M. C. (2001). The Impact of Domestic Work on Men's and Women's Wages. Journal of Marriage and Family, 63, 1134-1145. http://dx.doi.org/10.1111/j.1741-3737.2001.01134.x

Northcutt, C. A. (1991). Successful Career Women: Their Professional and Personal Characteristics. New York: Greenwood Press.

Organization for Economic Cooperation Development (OECD). (2003). Managing Senior Management: Senior Civil Service Reform in OECD Members Countries. Paris: OECD.

Perry, J. L. (1996). Measuring Public Service Motivation: An Assessment of Construct Reliability and Validity. Journal of Public Administration Research and Theory, 6(1), 5-22.

Perrewe, P., \& Nelson, D. L. (2004). The Facilitative Role of Political Skill. Organizational Dynamics, 33(4), 366-378. http://dx.doi.org/10.1016/j.orgdyn.2004.09.004

Presidential Committee on Government Innovation and Decentralization. (2004). A Korean Manual for Government Organization Diagnosis. Seoul: MOGAHA

Ragins, B. R. (1989). Barriers to Mentoring: The Female Manager's Dilemma. Human Relations, 42(1), 1-22. http://dx.doi.org/10.1177/001872678904200101

Schein, V. E. (1978). Sex role stereotyping, ability, and performance: Prior research and new directions. Personnel Psychology, 31(2), 259-268. 
Seibert, S. E., Crant, J. M., \& Kraimer, M. L. (1999). Proactive personality and career success. Journal of applied psychology, 84(3), 416-427.

Seibert, S. E., \& Kraimer, M. L. (2001). The five-factor model of personality and career success. Journal of vocational behavior, 58(1), 1-21. http://dx.doi.org/10.1006/jvbe.2000.1757

Seibert, S. E., Kraimer, M. L., \& Liden, R. C. (2001). A Social Capital Theory of Career Success. Academy of Management Journal, 44(2), 219-237. http://dx.doi.org/10.2307/3069452

Stewart, L. P., \& Gundykunst, W. B. (1982). Differential Factors Influencing the Hierarchical Level and Number of Promotions of Males and Females within an Organization. The Academy of Management Journal, 25(3), 586-597.

Tharenou, P., \& Conroy, D. (1994). Men and Women Manager's Advancement: Personal or Situational Determinants? Applied Psychology, 43(1), 5-31. http://dx.doi.org/10.1111/j.1464-0597.1994.tb00807.x

Tharenou, P., Latimer, S., \& Conroy, D. (1994). How Do You Make It To The Top? An Examination of Influences on Women's and Men's Managerial Advancement. Academy of Management Journal, 37(4), 899-931. . http://dx.doi.org/10.2307/256604

Torkar, D. M., \& Subich, L. M. (1997). Relative Contributions of Congruence and Personality Dimensions to Job Satisfaction. Journal of Vocational Behavior, 50, 482-491. http://dx.doi.org/10.1006/jvbe.1996.1546

Tower, L. E., \& Alkadry, M. G. (2008). The social costs of career success for women. Review of Public Personnel Administration, 28(2), 144-165. http://dx.doi.org/10.1177/0734371X08315343

Vertz, L. L. (1985). Women, occupational advancement, and mentoring: An analysis of one public organization. Public Administration Review, 415-423.

Wayne, S. J., Liden, R. C., Kraimer, M. L. \& Graf, I. K. (1999). The Role of Human Capital, Motivation and Supervisor Sponsorship in Predicting Career Success. Journal of Organizational Behavior, 20, 577-595. http://dx.doi.org/10.1002/(SICI)1099-1379(199909)20:5<577::AID-JOB958>3.0.CO;2-0

White, J. K., Hendrick, S. S., \& Hendrick, C. (2004). Big Five Personality Variables and Relationship Constructs. Personality and Individual Differences, 37, 1519-1530. http://dx.doi.org/10.1016/j.paid.2004.02.019

Whitely, W. T., Dougherty, T. W., \& Dreher, G. F. (1991). Relationships of Career Mentoring to Early Career Progress. Academy of Management Journal, 34, 331-351. http://dx.doi.org/10.1177/017084069301400305

Willem, A., \& Buelens, M. (2007). Knowledge sharing in public sector organizations: The effect of organizational characteristics on interdepartmental knowledge sharing. Journal of public administration research and theory, 17(4), 581-606. http://dx.doi.org/10.1093/jopart/mul021

Yoo, M., \& Yim, D. (2004). Public Personnel Management. Seoul: Parkyoungsa.

\section{Notes}

Note 1. 'Won' is the monetary unit of Korea.

Note 2. According to this manual, the Presidential Committee on Government Innovation and Decentralization conducted the organization diagnosis for the Korean central government in 2004.

Note 3. Min, Lee and Chung (1997) standardized the Korean version of NEO-PI-R, which translated Costa and Mcrae (1992)'s NEO-PI-R into Korean.

\section{Appendix}

Total number of female officials at the managerial level in the central government

\begin{tabular}{ccccc}
\hline Grade 1 & Grade 2 & Grade 3 & Grade 4 & Grade 5 \\
\hline 1 & 6 & 21 & 124 & 487 \\
\hline
\end{tabular}

Source. Internal data from the Civil Service Commission (2004)

\section{Copyrights}

Copyright for this article is retained by the author(s), with first publication rights granted to the journal.

This is an open-access article distributed under the terms and conditions of the Creative Commons Attribution license (http://creativecommons.org/licenses/by/3.0/). 